\title{
Faktor-Faktor yang Mempengaruhi Kejadian Abortus pada Ibu Hamil di Ruang Kebidanan Rumah Sakit Umum Daerah dr. Zainoel Abidin Pemerintah Aceh Tahun 2017
}

\author{
Factors Affecting Abortus's Event in Pregnant Woman in The Hospital Room \\ General Regional dr. Zainoel Abidin The Government of Aceh Year 2017
}

\author{
Ulfa Farrah Lisa ${ }^{* 1}$, Desi Harisna ${ }^{2}$ \\ ${ }^{1,2}$ Program Studi D-IV Bidan Pendidik, Fakultas Ilmu Kesehatan, Universitas Ubudiyah Indonesia, Banda Aceh, Indonesia \\ *Korespondensi Penulis: ulfa.farrah@uui.ac.id
}

\begin{abstract}
Abstrak
Frekuensi abortus spontan di Indonesia adalah 10\%-15\% dari 5 juta kehamilan setiap tahunnya atau 500.000 - 750.000. Sedangkan abortus buatan sekitar 750.000-1,5 juta setiap tahunnya. Berdasarkan Studi Pendahuluan dari data Rekam Medik Rumah Sakit Umum Daerah Daerah Zainoel Abidin di ruang Kebidanan Tahun 2016 jumlah pasien yang mengalami abortus pada tahun 2015 adalah 127 kasus, dan pada tahun 2016 berjumlah 153 kasus. Tujuan Penelitian untuk mengetahui faktor-faktor yang mempengaruhi kejadian abortus pada ibu hamil di ruang kebidanan Rumah Sakit Umum Daerah dr. Zainoel Abidin Pemerintah Aceh tahun 2017. Metode Penelitian,Penelitian ini menggunakan desain case control dengan retrospektif. Dilakukan pada tanggal 17-19 Juli 2017. Sampel dalam penelitian ini sebanyak $242 \mathrm{ibu}$, dimana proses pengambilan sampel menggunakan rumus Lameshow sehingga diperoleh sampel sebanyak $121 \mathrm{ibu}$ yang mengalami abortus dan $121 \mathrm{ibu}$ yang tidak mengalami abortus. Analisa data menggunakan analisa univariat dan bivariat, dimana uji statistik menggunakan uji chi square dan OR. Dari hasil analisa bivariat menunjukkan ada pengaruh kejadian abortus dengan umur ( $p$-value 0,001, OR = 7.842), paritas ( $p$-value $0,003, \mathrm{OR}=9.235)$, riwayat abortus ( $p$-value $0,002, \mathrm{OR}=10.291)$, dan jarak kehamilan ( $p$ value 0,010, OR $=2.886$ ). Dapat disimpulkan bahwa ada pengaruh antara umur, paritas, riwayat abortus dan jarak kelahiran dengan kejadian abortus. Diharapkan agar dapat menjadi masukan bagi tempat peneliti sehingga dapat memberikan masukan kepada tenaga kesehatan terhadap peningkatan penanganan pada pasien dengan kejadian abortus.
\end{abstract}

Kata Kunci : Kejadian abortus, umur, paritas, riwayat abortus dan jarak kelahiran

\section{Abstract}

The frequency of spontaneous abortion in Indonesia is 10\% -15\% of 5 million pregnancies annually or 500,000 - 750,000. While artificial abortus about 750.000-1,5 million every year. Based on Preliminary Study of Medical Record of Rumah Sakit Umum Daerah Daerah Zainoel Abidin di ruang Kebidanan of 2016 the number of aborted patients in 2015 was 127 cases, and in 2016 was 153 cases. The aim of this research is determine the factors that affect the incidence of abortion in pregnant women in midwife room Rumah Sakit Umum Daerah Daerah Zainoel Abidin di ruang Kebidanan $t$ in 2017.Research Method: This research use 
case control design with retrospective. Performed on 17-19 July 2017. The sample in this study as many as 242 mothers, where the process of sampling using the formula Lameshow so that obtained a sample of 121 mothers who have abortus and 121 women who do not have abortion. Data analysis using univariate and bivariate analysis, where statistical test using chi square and OR test. The results of bivariate analysis showed that there was a correlation between abortion occurrence and age ( $p$-value 0.001, OR = 7.842), parity ( $p$-value 0.003, OR $=9.235)$, abortion history ( $p$-value 0.002, OR $=10.291)$ and distance of pregnancy ( $p$ value $0.010, O R=2.886$ ). It can be concluded that there is a relationship between age, parity, history of abortion and the distance of birth with abortion. It is expected to be an input for the researcher's place so that it can provide input to health workers on improving treatment in patients with abortion events.

Keywords: Occurrence of abortion, age, parity, history of abortion and distance of birth

\section{PENDHULUAN}

Abortus merupakan masalah kesehatan masyarakat karena memberikan dampak pada kesakitan dan kematian ibu. Perdarahan pada kehamilan muda yang merupakan salah satu penyebab kematian neonatal dan maternal. Risiko terjadinya abortus spontan meningkat bersamaan dengan peningkatan jumlah paritas, usia ibu, riwayat abortus dan jarak kehamilan. Abortus meningkat sebesar $12 \%$ pada wanita usia kurang dari 20 tahun dan meningkat sebesar 26\% pada usia lebih dari 40 tahun (Cunningham, 2012).

Umur yang kemungkinan berisiko tinggi mengalami abortus pada saat kehamilan dan persalinan <20 tahun atau >35 tahun, serta Paritas tinggi (lebih dari 3) mempunyai angka kematian maternal lebih tinggi. Lebih tinggi paritas maka lebih tinggi resiko komplikasi dan kematian maternal. Resiko pada ibu yang kategori paritasnya primipara dapat ditangani dengan asuhan obstretrik lebih baik, sedangkan resiko pada paritas yang kategori multipara dan grandemulipara dapat dikurangi atau dicegah dengan keluarga berencana (Winkjosastro, 2010).

Riwayat abortus pada penderita abortus merupakan predisposisi terjadinya abortus berulang, setelah satu kali abortus pasangan punyai resiko $15 \%$ untuk mengalami keguguran lagi, sedangkan bila pernah keguguran 2 kali, resikonya akan meningkat 25\%. Bila jarak kelahiran dengan anak sebelumnya kurang dari 2 tahun rahim dan kesehatan ibu belum pulih dengan baik. Kehamilan dalam keadaan ini perlu diwaspadai karena ada kemungkinan pertumbuhan janin kurang baik (Prawirohardjo, 2010)

Frekuensi abortus spontan di Indonesia adalah 10\%-15\% dari 5 juta kehamilan setiap tahunnya atau 500.000 - 750.000, sedangkan abortus buatan sekitar 750.000-1,5 juta setiap 
tahunnya. Frekuensi ini dapat mencapai 50\% bila diperhitungkan mereka yang hamil sangat dini, terlambat haid beberapa hari sehingga wanita itu sendiri tidak mengetahui bahwa sudah hamil. Angka kematian karena abortus mencapai 2500 setiap tahunya. Dari 2,3 juta kasus yang terjadi di Indonesia, sekitar 1 juta terjadi secara spontan, 0,6 juta diaborsi karena kegagalan KB dan 0,7 diaborsi karena tidak digunakannya alat KB. Sedangkan di Provinsi Aceh dimana Angka Kematian Ibu (AKI) sebanyak 149,2 per 100.000 kelahiran hidup. Hal ini disebabkan oleh perdarahan $42 \%$, eklamsia $13 \%$, abortus $11 \%$, infeksi $10 \%$, persalinan macet 9\% dan penyebab lainnya $15 \%$ (Dinkes Aceh, 2015).

Kejadian abortus dapat disebabkan karena usia ibu yang masih terlalu muda yaitu kurang dari 20 tahun, dimana alat reproduksinya masih kurang maksimal, serta usia ibu yang tidak produktif lagi yaitu di atas 35 tahun karena penurunan daya tahan tubuh. Kejadian abortus dapat dialami oleh ibu yang terlalu banyak anak dan jarak anak terlalu dekat, dikarenakan kondisi rahim yang masih dalam penyembuhan sehingga mudah mengalami pendarahan. Selain itu, ibu yang pernah mengalami abortus lebih besar berisiko kembali mengalami abortus. Dari Studi Pendahuluan dari data Rekam Medik RSUD Zainoel Abidin di ruang Kebidanan Tahun 2016 jumlah pasien yang mengalami abortus pada tahun 2015 adalah 127 kasus, dan pada tahun 2016 berjumlah 153 kasus. Kecendrungan peningkatan angka kejadian abortus dari 1 tahun terakhir di RSUD Zainoel Abidin.

Berdasarkan permasalah di atas, penulis tertarik untuk mengangkat masalah tersebut untuk melakukan penelitian mengenai "faktor-faktor yang mempengaruhi kejadian abortus pada ibu hamil di ruang kebidanan RSUD dr. Zainoel Abidin Pemerintah Aceh tahun 2017”.

\section{METODE PENELITIAN}

Penelitian ini bersifat analitik dengan desain case control, yaitu pendekatan dengan studi retrospektif, yaitu bertujuan untuk mengetahui faktor- faktor yang berpengaruh dengan kejadian abortus pada ibu hamil diruang kebidanan RSUD dr. Zainoel Abidin Pemerintah Aceh tahun2017. Pengumpulan data ini telah dilaksanakan pada tanggal 20 Januari - 19 Juli 2017 di Ruang Kebidanan Rumah Sakit Umum Daerah dr. Zainoel Abidin Pemerintah Aceh. Populasi pada penelitian ini adalah kelompok kasus abortus yaitu semua ibu yang mengalami abortus dan kelompok kontrol yaitu ibu yang tidak mengalami abortus di RSUD dr. Zainoel Abidin Pemerintah Aceh sejak Januari s/d Desember 2016.

Instrumen pengumpulan data dalam penelitian ini adalah menggunakan data sekunder 
yaitu data yang didapat dari buku register di Ruang Kebidanan Rumah Sakit Umum Daerah dr Zainoel Abidin Pemerintah Aceh tentang kejadian abortus dari bulan Januari s/d Desember tahun 2016. Untuk menguji hipotesa dilakukan analisis statistik dengan menggunakan uji chisquare test pada tingkat kemaknaannya $\mathrm{CI}=95 \%, \alpha=5 \%(0,05)$ dan Odds Ratio (OR).

\section{HASIL DAN PEMBAHASAN}

Tabel 1. Distribusi Umur Ibu, Paritas, Riwayat Abortus, dan Jarak Kelahiran di Ruang Kebidanan Rumah Sakit Umum Daerah dr. Zainoel Abidin Banda Aceh Tahun 2017

\begin{tabular}{|c|c|c|c|c|c|c|c|}
\hline \multirow{3}{*}{ No } & \multirow{3}{*}{ Katagori } & \multicolumn{4}{|c|}{ Kelompok } & \multirow{2}{*}{\multicolumn{2}{|c|}{ Total }} \\
\hline & & \multicolumn{2}{|c|}{ Kasus } & \multicolumn{2}{|c|}{ Kontrol } & & \\
\hline & & $\mathbf{n}$ & $\%$ & $\mathbf{n}$ & $\%$ & $\mathbf{n}$ & $\%$ \\
\hline \multicolumn{8}{|c|}{ Umur } \\
\hline 1 & Berisiko & 68 & 56,2 & 17 & 14,0 & 85 & 35,1 \\
\hline 2 & Tidak berisiko & 53 & 78,5 & 104 & 86,0 & 157 & 64,9 \\
\hline \multicolumn{8}{|c|}{ Paritas } \\
\hline 1 & 1 anak & 61 & 50,4 & 12 & 9,9 & 73 & 30,2 \\
\hline 2 & $>1$ anak & 60 & 49,6 & 109 & 90,1 & 169 & 69,8 \\
\hline \multicolumn{8}{|c|}{ Riwayat Abortus } \\
\hline 1 & Pernah & 51 & 42,1 & 8 & 6,6 & 59 & 24,4 \\
\hline 2 & Tidak Pernah & 70 & 57,9 & 113 & 93,4 & 183 & 75,6 \\
\hline \multicolumn{8}{|c|}{ Jarak Kelahiran } \\
\hline 1 & Beresiko & 82 & 67,8 & 51 & 42,1 & 133 & 55,0 \\
\hline 2 & Tidak Beresiko & 39 & 32,2 & 70 & 57,9 & 109 & 45,0 \\
\hline
\end{tabular}

Sumber : Data Sekunder

Berdasarkan tabel di atas dapat dilihat bahwa dari 242 responden yang umurnya ketegori tidak berisiko sebanyak 64,9\%, paritasnya pada kategori > 1 anak sebanyak 69,8\%, riwayat abortusnya pada kategori tidak pernah sebanyak 75,9\%, jarak kelahirannya pada kategori beresiko sebanyak 55,0\%. 
Tabel 2. Pengaruh Paritas dengan Kejadian Abortus di Ruang Kebidanan Rumah Sakit Umum Daerah dr. Zainoel Abidin Banda Aceh Tahun 2017

\begin{tabular}{|c|c|c|c|c|c|c|c|c|c|}
\hline \multirow{3}{*}{ No } & \multirow{3}{*}{ Umur } & \multicolumn{4}{|c|}{ Kelompok } & \multirow{2}{*}{\multicolumn{2}{|c|}{ Total }} & \multirow{3}{*}{$\begin{array}{c}P \\
\text { value }\end{array}$} & \multirow{3}{*}{ OR } \\
\hline & & \multicolumn{2}{|c|}{ Kasus } & \multicolumn{2}{|c|}{ Kontrol } & & & & \\
\hline & & $\mathbf{n}$ & $\%$ & $\mathbf{n}$ & $\%$ & $\mathbf{n}$ & $\%$ & & \\
\hline 1. & Berisiko & 68 & 56,2 & 17 & 14 & 85 & 35,1 & \multirow{2}{*}{0,001} & \multirow{2}{*}{7,842} \\
\hline 2. & Tidak berisiko & 53 & 78,5 & 104 & 86 & 157 & 64,9 & & \\
\hline & Jumlah & 121 & 100 & 121 & 100 & 242 & 100 & & \\
\hline
\end{tabular}

Sumber : Data Sekunder

Berdasarkan tabel di atas, bahwa dari 85 responden yang umurnya pada kategori berisiko sebanyak 68 orang (56,2\%) mengalami kejadian abortus, sedangkan dari 157 responden yang umurnya pada kategori tidak berisiko sebanyak 104 orang (86,0\%) tidak mengalami kejadian abortus. Setelah dilakukan uji statistik dengan menggunakan uji ChiSquare didapatkan nilai p-value $0.001(\mathrm{p}<0.05)$ dan $\mathrm{OR}=7.842$.

Tabel 3. Pengaruh Paritas dengan Kejadian Abortus di Ruang Kebidanan Rumah Sakit Umum Daerah dr. Zainoel Abidin Banda Aceh Tahun 2017

\begin{tabular}{|c|c|c|c|c|c|c|c|c|c|}
\hline \multirow{3}{*}{ No } & \multirow{3}{*}{ Paritas } & \multicolumn{4}{|c|}{ Kelompok } & \multirow{2}{*}{\multicolumn{2}{|c|}{ Total }} & \multirow{3}{*}{$\begin{array}{c}P \\
\text { value }\end{array}$} & \multirow{3}{*}{ OR } \\
\hline & & \multicolumn{2}{|c|}{ Kasus } & \multicolumn{2}{|c|}{ Kontrol } & & & & \\
\hline & & n & $\%$ & $\mathbf{n}$ & $\%$ & $\mathbf{n}$ & $\%$ & & \\
\hline 1. & 1 anak & 61 & 50,4 & 12 & 9,9 & 73 & 30,2 & & \\
\hline 2. & $>1$ anak & 60 & 49,6 & 109 & 90,1 & 169 & 69,8 & 03 & 5 \\
\hline & Jumlah & 121 & 100 & 121 & 100 & 242 & 100 & & \\
\hline
\end{tabular}

Sumber : Data Sekunder

Berdasarkan tabel di atas, bahwa dari 73 responden yang paritasnya pada kategori 1 anak sebanyak 61 orang $(50,4 \%)$ mengalami kejadian abortus, sedangkan dari 169 responden yang paritasnya pada kategori > 1 anak sebanyak 109 orang $(90,1 \%)$ tidak mengalami kejadian abortus. Setelah dilakukan uji statistik dengan menggunakan uji Chi-Square didapatkan nilai $\mathrm{p}$-value $0.003(\mathrm{p}<0.05)$ dan $\mathrm{OR}=9.235$ 
Tabel 4. Pengaruh Riwayat Abortus dengan Kejadian Abortus di Ruang Kebidanan Rumah Sakit Umum Daerah dr. Zainoel Abidin Banda Aceh Tahun 2017

\begin{tabular}{|c|c|c|c|c|c|c|c|c|c|}
\hline \multirow{3}{*}{ No } & \multirow{3}{*}{$\begin{array}{l}\text { Riwayat } \\
\text { Abortus }\end{array}$} & \multicolumn{4}{|c|}{ Kelompok } & \multirow{2}{*}{\multicolumn{2}{|c|}{ Total }} & \multirow{3}{*}{$\begin{array}{c}P \\
\text { value }\end{array}$} & \multirow{3}{*}{$\mathbf{O R}$} \\
\hline & & \multicolumn{2}{|c|}{ Kasus } & \multicolumn{2}{|c|}{ Kontrol } & & & & \\
\hline & & $\mathbf{n}$ & $\%$ & $\mathbf{n}$ & $\%$ & n & $\%$ & & \\
\hline 1. & Pernah & 51 & 42,1 & 8 & 6,6 & 59 & 24,4 & \multirow{2}{*}{0,003} & \multirow{2}{*}{9,235} \\
\hline 2. & Tidak Pernah & 70 & 57,9 & 113 & 93,4 & 183 & 75,6 & & \\
\hline & Jumlah & 121 & 100 & 121 & 100 & 242 & 100 & & \\
\hline
\end{tabular}

Sumber : Data Sekunder

Berdasarkan tabel di atas, bahwa dari 59 responden yang riwayat abortus pada kategori pernah sebanyak 51 orang $(42,1 \%)$ mengalami kejadian abortus, sedangkan dari 183 responden yang riwayat abortusnya pada kategori tidak pernah sebanyak 113 orang $(93,4 \%)$ tidak mengalami kejadian abortus. Setelah dilakukan uji statistik dengan menggunakan uji Chi-Square didapatkan nilai p-value $0.002(\mathrm{p}<0.05)$, dan $\mathrm{OR}=10.291$.

Tabel 5. Pengaruh Jarak Kelahiran dengan Kejadian abortus di Ruang Kebidanan Rumah Sakit Umum Daerah dr. Zainoel Abidin Banda Aceh Tahun 2017

\begin{tabular}{|c|c|c|c|c|c|c|c|c|c|}
\hline \multirow{3}{*}{ No } & \multirow{3}{*}{$\begin{array}{c}\text { Jarak } \\
\text { Kelahiran }\end{array}$} & \multicolumn{4}{|c|}{ Kelompok } & \multirow{2}{*}{\multicolumn{2}{|c|}{ Total }} & \multirow{3}{*}{$\begin{array}{c}P \\
\text { value }\end{array}$} & \multirow{3}{*}{ OR } \\
\hline & & \multicolumn{2}{|c|}{ Kasus } & \multicolumn{2}{|c|}{ Kontrol } & & & & \\
\hline & & $\mathbf{n}$ & $\%$ & $\mathrm{n}$ & $\%$ & $\mathbf{n}$ & $\%$ & & \\
\hline 1. & Beresiko & 82 & 67,8 & 51 & 42,1 & 133 & 24,4 & & \\
\hline \multirow[t]{2}{*}{2.} & $\begin{array}{l}\text { Tidak } \\
\text { Beresiko }\end{array}$ & 39 & 32,2 & 70 & 57,9 & 109 & 75,6 & 0,010 & 2,886 \\
\hline & Jumlah & 121 & 100 & 121 & 100 & 242 & 100 & & \\
\hline
\end{tabular}

Sumber : Data Sekunder

Berdasarkan tabel 4.6 dapat dilihat bahwa dari 133 responden yang jarak kelahirannya pada kategori beresiko sebanyak 82 orang $(67,8 \%)$ mengalami kejadian abortus, sedangkan dari 109 responden yang jarak kelahirannya pada kategori tidak berisiko sebanyak 70 orang (57,9\%) tidak mengalami kejadian abortus. Setelah dilakukan uji statistik dengan menggunakan uji Chi-Square didapatkan nilai p-value $0.010(\mathrm{p}<0.05)$ dan $\mathrm{OR}=2.886$.

\section{Pembahasan}

1. Pengaruh Umur dengan Kejadian Abortus

Berdasarkan tabel 2 dapat dilihat bahwa dari 85 responden yang umurnya pada kategori berisiko sebanyak 68 orang $(56,2 \%)$ mengalami kejadian abortus, sedangkan dari 
157 responden yang umurnya pada kategori tidak berisiko sebanyak 104 orang $(86,0 \%)$ tidak mengalami kejadian abortus.

Setelah dilakukan uji statistik dengan menggunakan uji Chi-Square didapatkan nilai p-value $0.001(\mathrm{p}<0.05)$, berarti ada pengaruh antara umur dengan kejadian abortus, dimana semakin umurnya pada kategori berisiko maka responden semakin berisiko mengalami kejadian abortus. Hal ini berarti hipotesa dalam penelitian ini Ha diterima. Serta dari hasi $\mathrm{OR}=7.842$ menunjukkan bahwa responden yang umurnya berisiko memiliki peluang 7.842 kali lebih besar mengalami kejadian abortus.

Umur seorang ibu berkaitan dengan alat reproduksi wanita. Umur reproduksi yang sehat dan aman adalah pada umur 20-35 tahun. Pada umur >35 tahun terkait dengan kemunduran dan penurunan daya tahan tubuh serta berbagai penyakit yang sering menimpa di umur ini. Kenyataannya sebagian perempuan hamil berumur dibawah 20 tahun dan tidak sedikit pula yang mengandung di atas umur 35 tahun. Padahal kehamilan yang terjadi dibwah umur 20 tahun mupun diatas umur 35 tahun termasuk berisiko, karena dibayangbayangi beragam factor gangguan (Bobak, 2012).

Hasil penelitian menunjukkan bahwa umur berpengaruh dengan kejadian abortus. Hal ini sesuai dengan penelitian yang dilakukan oleh Andriza (2013) dengan judul penelitian "Pengaruh Umur dan Paritas Ibu Hamil dengan Kejadian Abortus di RS Muhammadiyah Palembang” yang menyatakan bahwa adanya pengaruh yang bermakna antara umur dengan kejadian abortus dengan nilai p-value $=0,009$.

Menurut asumsi peneliti dimana wanita umur subur yang berumur $<20$ tahun atau $\geq$ 40 tahun lebih sering mengalami kejadian abortus dibandingkan dengan wanita dengan umur 20-40 tahun. Hal ini dikarenakan pada umur dibawah 20 tahun fungsi reproduksi seorang wanita belum berkembang dengan sempurna, sedangkan pada umur diatas 35 tahun fungsi reproduksi seorang wanita sudah mengalami penurunan dibandingkan fungsi reproduksi normal sehingga kemungkinan untuk terjadinya komplikasi pasca abortus terutama perdarahan akan lebih besar. Oleh karena itu, usia seorang wanitas sekitar 20-40 tahun system reproduksi sudah berfungsi secara optima, sehingga dapat memperkecil faktor risiko yang dapat menyebabkan terjadinya abortus. 


\section{Pengaruh Paritas dengan Kejadian Abortus}

Berdasarkan tabel 3 dapat dilihat bahwa dari 73 responden yang paritasnya pada kategori 1 anak sebanyak 61 orang $(50,4 \%)$ mengalami kejadian abortus, sedangkan dari 169 responden yang paritasnya pada kategori > 1 anak sebanyak 109 orang $(90,1 \%)$ tidak mengalami kejadian abortus.

Setelah dilakukan uji statistik dengan menggunakan uji Chi- Square didapatkan nilai p-value $0.003(\mathrm{p}<0.05)$, berarti ada pengaruh antara paritas dengan kejadian abortus, dimana semakin paritasnya pada kategori 1 anak maka responden semakin berisiko mengalami kejadian abortus. Hal ini berarti hipotesa dalam penelitian ini Ha diterima. Serta dari hasi OR $=9.235$ menunjukkan bahwa responden yang paritasnya pada kategori 1 anak memiliki peluang 9.235 kali lebih besar mengalami kejadian abortus.

Paritas merupakan jumlah kehamilan yang menghasilkan janin hidup, bukan jumlah janin yang dilahirkan. Janin yang lahir hidup atau mati setelah viabilitas dicapai, tidak mempengaruhi paritas. Paritas dibagi kedalam tiga kategori, yaitu primipara, multipara dan grandemultipara. Primipara adalah wanita yang telah melahirkan sebanyak 1 kali. Multipara adalah wanita yang telah pernah melahirkan anak hidup 2 kali sampai dimana persalinan tersebut tidak lebih dari pada 5 kali. Sedangkan grandemultipara yaitu wanita yang telah melahirkan janin aterm lebih dari 5 kali (Hamilton, 2012).

Hasil penelitian menunjukkan bahwa paritas berpengaruh dengan kejadian abortus. Hal ini sesuai dengan penelitian yang dilakukan oleh Qurratu A (2015) dengan judul penelitian "Pengaruh Faktor Risiko Anemia dengan Kejadian Abortus Spontan di RSUP.DR.M.Djamil Padang” yang menyatakan bahwa adanya pengaruh yang bermakna antara paritas dengan kejadian abortus dengan nilai p-value $=0,010$.

Menurut asumsi peneliti dimana wanita dengan paritas pada kategori 1 anak lebih sering mengalami kejadian abortus dibandingkan dengan wanita dengan telah memiliki lebih dari 1 anak. Hal ini dikarenakan pada paritas 1 anak fungsi reproduksi seorang wanita masih kurang maksimal dibandingkan fungsi reproduksi normal sehingga kemungkinan untuk terjadinya komplikasi pasca abortus terutama perdarahan akan lebih besar. Akan tetapi, seorang wanita yang telah memiliki anak lebih dari 1 orang juga dapat berisiko mengalami abortus, hal ini disebabkan karena seorang ibu memiliki riwayat abortus, serta umur ibu yang telah terlalu tua sehingga lebih besar berisiko mengalami abortus. 


\section{Pengaruh Riwayat Abortus dengan Kejadian Abortus}

Berdasarkan tabel 4 dapat dilihat bahwa dari 59 responden yang riwayat abortus pada kategori pernah sebanyak 51 orang $(42,1 \%)$ mengalami kejadian abortus, sedangkan dari 183 responden yang riwayat abortusnya pada kategori tidak pernah sebanyak 113 orang $(93,4 \%)$ tidak mengalami kejadian abortus.

Setelah dilakukan uji statistik dengan menggunakan uji Chi-Square didapatkan nilai p-value $0.002(\mathrm{p}<0.05)$, berarti ada pengaruh antara riwayat abortus dengan kejadian abortus, dimana semakin riwayat abortusnya pada kategori pernah maka responden semakin berisiko mengalami kejadian abortus. Hal ini berarti hipotesa dalam penelitian ini Ha diterima. Serta dari hasi OR $=10.291$ menunjukkan bahwa responden yang riwayat abortusnya pada kategori pernah mengalami abortus memiliki peluang 10.291 kali lebih besar mengalami kejadian abortus.

Penanganan pada kasus abortus spontan dapat dilakukan dengan beberapa tindakan yaitu, kuretase sampai pada histerektomi. Komplikasi dari tindakan kuretase adalah akan memberikan perubahan pada permeabilitas otot dinding rahim yang akan mempengaruhi kemampuan desidua basalis saat menerima implantasi embrio pada kehamilan selanjutnya. Kondisi endometrium setelah tindakan kuretase dapat berpotensi menyebabkan keguguran spontan. Sebelum tindakan kuretase dilakukan akan disuntikkan beberapa obat yang akan mempengaruhi kondisi rahim dan kondisi serviks (otot segmen bawah rahim) (Halminto, 2012).

Hasil penelitian menunjukkan bahwa riwayat abortus berpengaruh dengan kejadian abortus. Hal ini sesuai dengan penelitian yang dilakukan oleh Andesia, M (2014) dengan judul penelitian "Faktor-Faktor yang Berpengaruh dengan Kejadian Abortus di Ruang Kebidanan RSUD Mayjend. HM. Ryacudu Kota Bumi”yang menyatakan bahwa adanya pengaruh yang bermakna antara riwayat abortus dengan kejadian abortus dengan nilai pvalue $=0,003$.

Menurut asumsi peneliti dimana ibu dengan riwayat abortus pada kategori pernah lebih besar berisiko mengalami kejadian abortus dibandingkan dengan ibu yang riwayat abortus pada kategori tidak pernah. Sedangkan ibu yang riwayat abortus pada kategori tidak pernah lebih kecil mengalami kejadian abortus. Akan tetapi ibu yang tidak memiliki riwayat abortus juga dapat berisiko mengalami abortus. Hal ini dikarenakan, ibu baru 
pertama kali mengalami proses kehamilan, serta jarak antara 1 anak dengan anak yang lain terlalu dekar sehingga ibu lebih besar berisiko mengalami abortus.

\section{Pengaruh Jarak Kehamilan dengan Kejadian Abortus}

Berdasarkan tabel 5 dapat dilihat bahwa dari 133 responden yang jarak kelahirannya pada kategori beresiko sebanyak 82 orang $(67,8 \%)$ mengalami kejadian abortus, sedangkan dari 109 responden yang jarak kelahirannya pada kategori tidak berisiko sebanyak 70 orang $(57,9 \%)$ tidak mengalami kejadian abortus.

Setelah dilakukan uji statistik dengan menggunakan uji Chi-Square didapatkan nilai p-value $0.010(\mathrm{p}<0.05)$, berarti ada pengaruh antara jarak kelahiran dengan kejadian abortus, dimana semakin jarak kelahirannya pada kategori berisiko maka responden semakin berisiko mengalami kejadian abortus. Hal ini berarti hipotesa dalam penelitian ini Ha diterima. Serta dari hasi OR = 2.886 menunjukkan bahwa responden yang jarak kelahirannya pada kategori berisiko memiliki peluang 2.886 kali lebih besar mengalami kejadian abortus.

Jarak kehamilan $<2$ tahun dan $>4$ tahun tergolong resiko tinggi karena menimbulkan berbagai komplikasi pada abortus dimana uterus akan berkontraksi kurang baik dan melemah sehingga dapat mengakibatkan terlepasnya sebagian plasenta, robekan-robekan pada sinus-sinus maternalis. Bila jarak antar kelahiran dengan anak sebelumnya kurang dari 2 tahun, rahim dan kesehatan ibu belum pulih dengan baik. Kehamilan dalam keadaan ini perlu diwaspadai karena ada kemungkinan terjadinya perdarahan pasca abortus (Winkjosastro, 2010).

Hasil penelitian menunjukkan bahwa riwayat abortus berpengaruh dengan kejadian abortus. Hal ini sesuai dengan penelitian yang dilakukan oleh Andesia, M (2014) dengan judul penelitian "Faktor-Faktor yang Berpengaruh dengan Kejadian Abortus di Ruang Kebidanan RSUD Mayjend. HM. Ryacudu Kota Bumi”yang menyatakan bahwa adanya pengaruh yang bermakna antara jarak kelahiran dengan kejadian abortus dengan nilai pvalue $=0,024$.

Menurut asumsi peneliti dimana ibu dengan jarak kelahiran $<2$ tahun dan $>4$ tahun lebih sering mengalami kejadian abortus dibandingkan dengan ibu dengan jarak kelahiran 2-4 tahun. Hal ini dikarenakan pada jarak kelahiran $<2$ tahun memiliki fungsi reproduksi seorang wanita belum mengalami mencapai kesembuhan (kembali ke keadaan normal) 
dibandingkan ibu dengan jarak kelahiran 2-4 tahun dimana fungsi organ reproduksinya sudah kembali seperti normal. Ibu yang jarak kelahirannya jauh juga dapat berisiko mengalami abortus. Hal ini dikarenakan, ibu memiliki riwayat abortus, umur ibu yang terlalu muda menyebabkan ibu lebih besar berisiko mengalami abortus.

\section{DAFTAR PUSTAKA}

Andesia, M, 2014, Faktor-Faktor yang Berhubungan dengan Kejadian Abortus di Ruang Kebidanan RSUD Mayjend. HM. Ryacudu Kota Bumi, Bandar Lampung: Universitas Malahayati

Andriza, 2013, Hubungan Umur dan Paritas Ibu Hamil dengan Kejadian Abortus di RS Muhammadiyah Palembang, Palembang: STIK Bina Husada.

Bobak , 2012, Buku Ajar Keperawatan Maternitas. Jakarta: EGC Cunningham, 2012, Obstetri Williams. Jakarta : EGC

Dahlan, S, 2012, Statistik Untuk Kedokteran dan Kesehatan. Jakarta: Salemba Medika.

Dinkes Provinsi Aceh, 2015, Profil Kesehatan Provinsi Aceh, Banda Aceh: Dinkes Aceh

Halminto, 2012, Dasar-Dasar Keperawatan Maternitas, Jakarta: EGC. Hastono, S, 2010, Statistik Kesehatan, Jakarta: UI

Prawirohardjo, S, 2010, Buku Acuan nasional Pelayanan Kesehatan Maternal dan Neonatural, Jakarta: EGC.

Winkjosastro, 2010, Ilmu Kebidanan. Jakarta: Yayasan Bina Pustaka

Qurratu A, 2015, Hubungan Faktor Risiko Anemia dengan Kejadian Abortus Spontan di RSUP. DR. M. Djamil Padang, Padang: Universitas Andalas 